\title{
Psychosocial risks related to the nurse in the psychiatric hospital and management strategies
}

\author{
Riscos psicossociais relacionados ao enfermeiro no hospital psiquiátrico e estratégias de gerenciamento \\ Riesgos psicosociales relacionados al enfermero en un hospital psiquiátrico y estrategias de gestión
}

\section{Maria Carolina Santos Scozzafave ' \\ ORCID: 0000-0002-2438-4171}

Laura Andrian Leal ${ }^{\prime}$

ORCID: 0000-0002-8563-8980

Mirelle Inácio Soares '

ORCID: 0000-0002-5298-8634

Silvia Helena Henriques '

ORCID: 0000-0003-2089-3304

'Universidade de São Paulo. Ribeirão Preto, São Paulo, Brazil.

How to cite this article:

Scozzafave MCS, Leal LA, Soares MI, Henriques SH. Psychosocial risks related to the nurse in the psychiatric hospital and management strategies. Rev Bras Enferm [Internet]. 2019;72(4):834-40. doi: http://dx.doi.org /10.1590/0034-7167-2017-0311

Corresponding Author

Silvia Helena Henriques

E-mail: shcamelo@eerp.usp.br

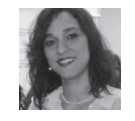

Submission: 05-08-2017

Approval: 02-20-2019

\begin{abstract}
Objective: To characterize the presence of psychosocial risks related to the work of the nurse in a psychiatric hospital and the strategies for managing these risks. Methods: Qualitative, in which 25 nurses from a psychiatric hospital participated using semistructured interviews from November 2014 to January 2015. Data analysis was performed using the thematic method. Results: The results showed psychosocial risks related to the work of psychiatric nurses, such as: insufficient academic training; lack of preparation and maintenance of equipment; poor relationship with colleagues; shortage of human resources and lack of capacity building; conflict between the demands of the home and work, as well as strategies for managing psychosocial risks such as family, cinema, music, reading, among others. Final considerations: This study should provoke the reflection of managers and future nurses regarding the working conditions in a psychiatric hospital and possible psychosocial risks to which they are exposed.
\end{abstract}

Descriptors: Occupational Risks; Nurses; Strategies; Hospitals; Violence.

\section{RESUMO}

Objetivo: Caracterizar a presença de riscos psicossociais relacionados ao trabalho do enfermeiro em um hospital psiquiátrico e as estratégias de gerenciamento desses riscos. Métodos: Pesquisa qualitativa, realizada no período de novembro de 2014 a janeiro de 2015, da qual participaram 25 enfermeiros de um hospital psiquiátrico, que responderam a entrevistas semiestruturadas. A análise dos dados foi realizada pelo método temático. Resultados: Os resultados mostraram problemas psicossociais relacionados ao trabalho dos enfermeiros psiquiátricos, como formação acadêmica insuficiente; falta de preparo e manutenção de equipamentos; pobre relacionamento com colegas; escassez de recursos humanos e falta de capacitação; e conflito entre exigências do lar, do trabalho e estratégias de gerenciamento dos riscos psicossociais, como recorrer à família, ao cinema, à música, à leitura etc. Considerações finais: Este estudo deve provocar a reflexão dos gestores e futuros enfermeiros quanto às condições de trabalho em hospital psiquiátrico e aos riscos psicossociais a que podem estar expostos.

Descritores: Riscos Ocupacionais; Enfermeiros; Estratégias; Hospitais; Violência.

\section{RESUMEN}

Objetivo: Identificar la presencia de riesgos psicosociales relacionados al trabajo del enfermero en un hospital psiquiátrico y las estrategias de gestión de esos riesgos. Métodos: Estudio cualitativo, del cual participaron 25 enfermeros de un hospital psiquiátrico, en el que se utilizaron entrevistas semiestructuradas en el período de noviembre de 2014 a enero de 2015 . Se realizó el análisis de datos mediante el método temático. Resultados: Los resultados mostraron la existencia de problemas psicosociales relacionados al trabajo de los enfermeros psiquiátricos, como: la insuficiente formación académica; la falta de preparación y mantenimiento de equipos; la escasa relación con los compañeros de trabajo; la escasez de recursos humanos y falta de capacitación; y el conflicto entre las exigencias del hogar y del trabajo, así como las estrategias de gestión de los riesgos psicosociales como recurrir a la familia, cine, música, lectura, entre otros. Consideraciones finales: Este estudio permite provocar la reflexión de los gestores y futuros enfermeros sobre las condiciones laborales en el hospital psiquiátrico y los posibles riesgos psicosociales a los que están expuestos.

Descriptores: Riesgos Laborales; Enfermeros; Estrategias; Hospitales; Violencia. 


\section{INTRODUCTION}

In the field of health, the uniqueness of hospital organizations have been marked by assisting patients in critical health conditions that needed individual responses to their real situation, in an environment that might make the various professional categories that work in it ill as well ${ }^{(1)}$. The nursing professional has hierarchical and conflicting characteristics, seeking his/her scientific identity by providing care. In addition to the difficulties of the occupation and the emotional distress of dealing with ill people and their families, the worker still faces risk situations, low wages, lack of recognition and environmental stress in the midst of several conceptions and cultures ${ }^{(2)}$.

The hospital environment has biological, ergonomic, chemical, physical, and psychosocial hazards. Psychosocial risks, focus of this investigation, are related to the design, organization and management of the occupation and to their social and environmental contexts, which have the potential to cause physical, psychological or social damage to the worker ${ }^{(3)}$.

To avoid negative effects of psychosocial risks in the safety and health of workers, specialists of the European Agency for Safety and Health at Work and the European Risk Observatory have identified work-related psychosocial risks that can affect the physical and mental health of workers and that would be distributed in five broad categories: 1) new forms of employment and job insecurity; 2) ageing of the workforce; 3) intensification of the work; 4) heavy emotional burden at work; and 5) lack of balance between family and work life ${ }^{(4)}$. Recently, emerging psychosocial risks were also identified in the work environment of nurses in psychiatric hospital units, including violence suffered by the nursing staff, which impacts the quality of life of these professionals $^{(5)}$.

In the environment of psychiatric units, natural stressors and high rates of professional absenteeism coexist, which results in dissatisfaction of workers. Studies show that customer satisfaction and the quality of life at work are related to favorable working conditions, such as sufficient human resources, in order to avoid overload, career plans and training(6).

Hospital nurses carry out multiple tasks, with different degrees of requirements and responsibilities, and, depending on the environment and the way in which the work is planned and organized, these professionals can be exposed to psychosocial risks. In psychiatric hospital units, the environment and the type of demand can expose the nurses to risks that significantly change the organization of work. That is the case of psychosocial risks, which result in negative consequences for the worker's health and the quality of care provided to patients.

Given the exposed, this study presents the following questions: what are the psychosocial risks faced by nurses who work in psychiatric hospitals? Have the organization and/or workers mobilized strategies to manage the risks?

In recent decades, significant changes have been made in work environments, with important technological advances associated with the globalization process. Such modifications showed visible repercussions in the work organization, especially in the context of psychiatric institutions, bringing new challenges to occupational health and safety. Thus, the concern with this issue is unquestionable, since the psychosocial risks must be considered to protect the health of workers ${ }^{(7)}$.

To identify the psychosocial risks in psychiatric nursing provides to these workers thoughts on the characteristics of their work by showing them opportunities to manage risks inherent in their occupation. Also, the identification of these risks is relevant to establish a consensus on the complexity of the psychosocial environment.

\section{OBJECTIVE}

Characterize, from the nurses' perception, the psychosocial risks of working in a psychiatric hospital and management strategies.

\section{METHODS}

\section{Ethical aspects}

This study was approved by the Research Ethics Committee of the Ribeirão Preto College of Nursing of University of São Paulo (EERP-USP) under protocol CAAE: 33723714.5.0000.5393, and all participants signed the informed consent form.

\section{Type of study}

It is a descriptive study of qualitative nature developed with semi-structured interviews.

\section{Scenario and participants in the study}

The scenario was a public psychiatric hospital, from the interior of São Paulo, a reference of the Unified Health System (SUS) in promoting psychiatric hospitalizations and integral assistance to people with mental disorders.

Nurses who worked at the hospital for more than six months since the beginning of data collection participated in the research. This time allows the professional experiences to identify psychosocial risks in the workplace.

\section{Data collection and organization}

To collect the data, semi-structured interviews were recorded in audio and subsequently transcribed, with scripts tested on psychiatric nurses who did not participate in the collection. The script contained two parts: the first with questions regarding data about the participants, such as age, sex, year of graduation and period of employment in the institution; the second with open-ended questions related to their profile to work in a hospital, environment conditions, functions in the organization, and workload scheme, in addition to the strategies developed to manage occupational hazards. Given this, 25 nurses participated in the investigation.

\section{Data analysis}

Data were analyzed and organized into thematic categories ${ }^{(8)}$ following three steps: pre-analysis, material exploration and processing of the results obtained. To identify the thematic units 
related to psychosocial risks, the speeches of those interviewed were considered in the light of the theoretical framework used ${ }^{(4)}$.

Data were grouped into two categories: "Work-related psychosocial risks of psychiatric nurses" and "Strategies for psychosocial risk management."

\section{RESULTS}

\section{Characterization of the participants}

Data showed female predominance (22-88\%), exposing the hegemony of women in nursing and corroborating other studies in which the female presence prevails ${ }^{(9)}$. Respondents were aged between 27 and 57 years.

Data showed that there are mental health professionals since the beginning of their careers, although researchers agree that the experiences in nursing can contribute to the planning, decisionmaking and mental health care processes ${ }^{(10)}$. As for the training of professionals, 24 nurses (96\%) held graduate degrees, 10 (40\%) being in the field of mental health/psychiatry; in addition, 10 nurses reported having completed at least two Lato Sensu graduate courses.

The workload of the nurses was 30 hours per week, 6 hours per day; however 12 (48\%) of them worked paid shifts at the hospital; five (20\%) nurses worked in the areas of assistance and teaching in other locations. One of the nurses had two employment relationships of 30 hours per week in the same hospital.

\section{Category 1:Work-related psychosocial risks of psychiatric nurses}

\section{Academic training and ability: insufficient education}

For participants, insufficient education in the field of mental health, especially regarding internships, is an occupational psychosocial risk.

The internship was very short, it was just 5 days, what enables me to work is the experience, the relationships, the daily routine, I think that just as all the other courses, psychiatry is little studied, we learn little about mental illness. (R9)

\section{Work environment and equipment: lack of repairs and maintenance of equipment}

The nurses reported that the physical structure of the unit lacks reliability and has precarious equipment without proper maintenance, which is considered a psychosocial risk for the worker.

[...] the structure is very precarious [...] we have a damaged infrastructure that requires constant reforms, obsolete materials that pose a risk for the worker and for the patient, and we also have a maintenance system that instead of making it easier, it hinders the work, besides being much complicated considering the structure [...] (R21)

\section{Interpersonal skills: poor relationship with colleagues and supervisors}

Interpersonal relationship was perceived as a psychosocial risk, when it becomes troubled and exhausting.
[...] I find the interpersonal relationship with co-workers and supervisors stressful, the nurse, besides having patients, has to deal with public administrators... as you start listening to everybody's problems, learning to share with them the responsibilities, but it is an exhausting process for the nurse. (R15)

\section{Workload: overload, long working hours}

The reports showed that nurses perform a large number of activities in their daily routine, dual function and overtime work. The adjustment to fulfil all tasks is not always appropriate, leading to work overload and, consequently, being a risk for the professional.

[...] a nurse has many tasks, we have to plan the nursing care and attend family meetings, in addition to all the other activities with patients, so the difficult part is being organized and handle all the tasks. (R25)

[...] In addition to working 30 hours per week to get a proper financial coverage, I need to do extra shifts [...] (R3)

\section{Human resources in nursing: scarcity, poor distribution of staff, lack of training}

The professionals reported insufficient number of nurses and the lack of training as hindering factors of the work process, which is considered a psychosocial risk.

[...] I think restraints are a complicated matter, sometimes the number of nurses is not enough to restrain a patient. (R9)

[...] In addition to the lack of nurses, there's also a lack of training, even though there are some courses, but I think they are not effective and do not have what the job demands. (R3)

\section{Work-family interface: conflicts between home and work demands, little time for the family}

To meet work and home demands is a psychosocial risk present in the daily life of the nurses participating in this research.

[...] I find it hard to reconcile the accumulation of functions with my family. (R6)

[...] / think the number of shifts I have to work affects my relationship with my husband; over the weekend I try to spend time with my family. I'm not satisfied with the time I spend with my family. (R7)

\section{Violence: fear and physical and emotional abuse}

Violence, emerging psychosocial risk, was reported by the participants in the study.

[...] the situation with my patients is always critical, anytime I can be beaten, you pass by and the patient is screaming, throwing things [...] a verbal, physical, emotional abuse is very tense [...], it makes you feel bad. (R10)

[...] the exhausting part is the problem with delinquents, the nurse is the target, we need to impose limits on the patient, which generates stress, I'm afraid to find those patients on the street. (R15) 


\section{Category 2: Strategies for psychosocial risk management}

The results showed that the institution does not offer activities that could improve the psychosocial working environment.

[...] I guess no institution provides resources, on the contrary, the work environment and the service encourage conflicts among staff members, with other staffs, with supervisors. (R2)

[...] the institution does nothing about it, it could give individual psychological support, even if annually. (R6)

However, individual strategies are developed by the professionals to mitigate situations of risk, such as spending time with the family, listening to music and reading.

[...] I try to have some leisure, I listen to music and go to the mall, meet friends and family, make some trips. (R5)

[...] I love reading, especially religious books and books focused on the psychology of human behavior. (R16)

\section{DISCUSSION}

The current trends in the promotion of health and safety at work include not only the physical, chemical and biological risks, but also the various psychosocial factors inherent in the institutions and the way they affect the physical and mental health of the worker.

Data investigation showed the education of nurses in the field of mental health and the workload of internships pose risks for these professionals, because they need theoretical and practical learning to work safely. Thus, although the internships have been cited as ways of learning, they were insufficient, with reduced course load and limited subsidies and expertise on the work practice.

In this regard, the undergraduate courses in nursing must constantly review its contents and course load of disciplines so the professional is able to efficiently meet the demands of the patients. About the field of psychiatry, a study shows that this course load represents less than $5 \%$ of all the contents of the course in nursing ${ }^{(11)}$. That is, although psychiatric nursing is a specialty, the course load offered is insufficient for the training of nurses who will work in this area.

As the training interferes in the risks faced by professionals, the hospitals concentrate countless risk factors to the health of workers, some of them hidden or unknown ${ }^{(12)}$. The structure can hinder or facilitate the care provided by the nurse and interfere effectively in the practice of mental health services ${ }^{(13)}$. On this premise, a certain discontent was observed regarding the structure, considered by some professionals one of the biggest problems of the institution and a potential psychosocial risk.

However, the psychosocial risks of the work environment and equipment, such as the precarious structure, the lack of appropriate space and equipment in poor condition, must be reconsidered by the management of the service. The concern with the structure is not based only on the need for personal comfort for everyday activities, but primarily on the desire to improve the patients' care and satisfactorily perform the planned activities ${ }^{(14)}$.
Another aspect raised was concerned with interpersonal relationship. By analyzing the speeches of the participants, we identified that the interpersonal relationship is a troubled and stressful psychosocial risk, corroborating the literature, which also considers it a psychosocial risk inherent in the work environment.

The beneficial interpersonal relationship among co-workers increases the efficient performance of professionals, being an indispensable item for the quality of nursing care. A good interpersonal relationship among staff members is extremely relevant so the care provided to patients is the best one possible and the development of professional activities is more enjoyable and satisfying for the workers ${ }^{(15)}$.

Given this, the interpersonal relationship can also interfere in the hierarchical organization of the nurses. Professionals who occupy positions hierarchically superior may establish different types of relationships and generate stressful situations. Subordinate relationships can be transformed by the communicative practice, because the implicit values in the speech acts allow us to discriminate and maintain the technical differences of jobs carried out by equal social subjects ${ }^{(16)}$. Good relationships in the workplace need to be guaranteed in order to minimize the dissatisfaction in the work environment ${ }^{(17)}$.

As well as the relationships, another important factor is the work overload in assistance. Workloads are subdivided into physical, chemical, biological, mechanical, physiological and psychic categories. Work overload due to psychic factors such as psychosocial risks is caused by prolonged stress situations, while work underload is caused by the limited use of knowledge and skills of the worker. Monotony, repeatability, slow- and fast-paced work, the interference of other works, the permanent attention, supervision, and the lack of autonomy are some of the psychological loads ${ }^{(18)}$

Characteristics in the organization of the work in the hospital environment are sources of pressure for professionals, and the extension of hours of work wears down the worker physically and psychologically, resulting in stress, mental distress and appearance of disorders, such as anxiety, depression and somatization ${ }^{(17)}$.

Another element highlighted by the participants that contributes to the perception of work overload is the accumulation of functions. This psychosocial risk appears when the nurses perform functions that could be done by other professionals.

It is noteworthy that the presence of risks, such as overload, fast-paced work and inadequate work schemes, bring consequences to workers, who become tired, exhausted, and sometimes stressed by the complexity of working in a psychiatric hospital.

Another element that causes work overload is the shortage of human resources in nursing. A study showed that the low number of staff members affects the quality of the service, generating risks to the patients' safety and to occupational health, being necessary to subsidize the sizing of human resources for patient care with higher quality and safety ${ }^{(19)}$.

When discussing issues that involve the management of human resources in health and specifically in nursing, it is essential to highlight the sizing of the staff, working conditions and other aspects that interfere in the care provided ${ }^{(20)}$. Regarding the training of the professionals, besides the insufficient number, the research showed the lack of training of staff members to work with the patients, another psychosocial risk. 
The nurse is responsible for managing the unit and the staff. In this sense, priorities should be established in order to overcome the lack of both training and staff members. The participation in specific scientific events and permanent education strategies contribute to reducing psychosocial risks.

Another aspect mentioned was related to work-family interface, with the presence of conflicts between home and work demands and little time spent with the family. The balance between work and family responsibilities is very challenging. This reality affects particularly women, who are at a disadvantage in the labor market. Thus, the balance between work and family is the key to gender equality in the labor market ${ }^{(21)}$.

However, the compliance with work and home demands is a psychosocial risk present in the daily lives of nurses. One of the factors that interfere in the work/family relationship are the long working hours and the accumulation of functions, which make it difficult for them to spend more time with their family.

We observed the workers have a perception about how the time spent with their family affects their relationships at home. Thus, the work-life balance can be influenced by psychosocial factors experienced in the work routine, and strategies to preserve the staff's personal well-being can improve these relationships. Conflicts between work and family life generate tensions and force them to choose between their job and their family(21).

Regarding the companies, the drawbacks include the economic cost of absenteeism, being late for work, the losses linked to a decrease in productivity among employees, the resistance to mobility and promotions, high employee turnover, and the difficulty in maintaining a competent staff, among others ${ }^{(22)}$.

Therefore, participants revealed that violence is a psychosocial risk related to working conditions; nurses are exposed to physical and emotional abuse every day in the hospital. We identified in this investigation, through the participants'reports, the violence on the part of patients against workers due to psychic decompensation.

Agitated and/or aggressive patients usually have low capacity of insight about their morbidity and limited critical judgment of the reality. Therefore, these patients may find it difficult to understand their condition and, consequently, do not recognize the need for outside help. Depending on the degree of agitation, these patients represent a risk to the physical integrity of the professionals and other patients ${ }^{(23)}$.

Among the health professionals, nurses are often exposed to situations of violence in their workplace, which brings negative consequences to their performance ${ }^{(24)}$. The nurses also reported that, in addition to physical assaults, offensive verbal threats are made against them and their families.

As a result of these physical and verbal assaults, nurses reported being afraid of the type of patient treated. The fear of the offender occurs not only in the workplace, but also when the workers return home, especially because the threats are directed to their families. In this sense, there are many forms of psychosocial risks faced by nursing professionals in their daily routine, so public administrators and hospital institutions need to reflect upon the risks presented to their employees, offering subsidies to maintain their health and the quality of the service provided.

Regarding the psychosocial risks identified, organizational and/or individual strategies must be developed to minimize or control stressful effects. As the organization of work extends its importance in the work/health relationship, new strategies are required to modify the working conditions. Positive work and a risk assessment system can be used by public administrators in the various workplaces to offer a suitable environment for employees, leading to greater productivity and efficiency in the service provided.

As for the organizational strategies, the results showed that the institution does not offer activities to improve the psychosocial working environment. Organizational strategies must mitigate risks inherent in the occupation, helping the professional make right decisions. These strategies, though they have not been observed, were recognized by the nurses as aspects that could facilitate and/or minimize the stressful effects of psychosocial risks.

In situations of suffering caused by the environment and working conditions, it is common for workers to implement defensive strategies to manage and prevent these situations. In the domain health versus work, professionals seek control over the work conditions and environment to make them healthier, using individual strategies to alleviate the consequences of occupational hazards. In this regard, we can observe the implementation of individual strategies promoted by the worker her/himself.

Being around family, children and loved ones seem to improve the ability of tackling the problems faced at work. Individuals respond to risk factors in the work environment differently, in a spontaneous and not planned way, and they try hard to adapt to that reality, in many cases, influenced by previous labor and personal experiences. Leisure activities, such as going to the mall, listening to music, walking, running, weight training, and others, were identified as resources used by nurses as a form of entertainment to help alleviate the distresses and troubles of work.

Leisure brings many benefits to quality of life, among them we can mention the fight against stress, which promotes inner body balance and collaborates to health maintenance ${ }^{(25)}$. Physical activities are known to release tensions, by adrenaline rush, and neurotransmitters such as endorphins, which are responsible for feelings of pleasure and well-being, working on the prevention and combat of difficult situations ${ }^{(26)}$. Also, several workers reported that physical activities eased their tensions.

Thus, with an appropriate psychosocial environment, work can be beneficial for the mental health of nurses, providing them with better quality of life and giving them a broad sense of social inclusion, identity and status, as well as career development opportunities and greater confidence. However, a negative work environment in psychosocial terms can have significant adverse consequences for the health of workers.

With this in mind, the implementation of administrators focused on people who value the nursing staff through dialogue, recognition, training programs focusing on personal and professional development, career plan and salaries and the worker's inclusion in the decision-making process should contribute to reducing risks in the environment and to increasing job satisfaction ${ }^{(27)}$.

\section{Limitations of the study}

The limitation of this research regards the professionals and the type of institution selected, as the study addressed only 
nurses and a single public institution. Thus, other professionals in the nursing staff who could also bring aspects of occupational hazards were not covered, as well as other institutions of legal nature. Given this, we recommend further studies including other professional categories to get a broader view of reality.

\section{Contributions to the fields of nursing, health or public policy}

This study shall fill knowledge gaps in the area covered, and the results shall provide subsidies for public administrators to know in detail the working conditions and psychosocial risks to which psychiatric nurses are exposed, and, hopefully, adopt measures and implement preventive and/or conservative strategies in the work environment to promote and protect the workers' health.

\section{FINAL CONSIDERATIONS}

The relationship between a nurse and a patient with mental disorder has complex situations related to direct assistance to the patient and work-related factors, which, depending on how they are organized, expose professionals to psychosocial risks that can lead to their distress.
Psychosocial risks identified in the psychiatric hospital investigated are distributed among the following categories: professional training, work environment and equipment, interpersonal relationships, workload scheme, human resources, work-family interface, and violence.

To manage psychosocial risks at work, preventive measures or targeted interventions must be implemented in the workplace, in addition to activities directed to workers individually. The activities may also include structural measures such as the implementation of policies for the management of occupational risks. Nurses must be educated about their vulnerability in relation to the psychosocial risks of their practice.

From this perspective, some coping strategies adopted by nurses were identified, such as: resort to the presence of the family, to movies, music, books, physical exercises and therapies, religion, trips; but we must highlight that the nurses did not report strategies of the organization to manage these risks.

Therefore, preventative measures need to be adopted in the profession to promote safety in the workplace, and the evaluative processes in organizations must be strengthened in order to show the situation of various services, generating discussions on which activities could improve the training and practice of psychiatric nurses.

\section{REFERENCES}

1. Camelo SHH. Professional competences of nurse to work in intensive care units: an integrative review. Rev Lat-Am Enfermagem [Internet]. 2012 [cited 2017 Apr 20];20(1):192-200. Available from: http://dx.doi.org/10.1590/S0104-11692012000100025

2. Foresto DR, Souza JLE. Síndrome de burnout: indicadores em enfermeiros da atenção primária. Rev Funec Cient Mult [Internet]. 2014 [cited 2017 Nov 10];3(5):110-21. Available from: https://doi.org/10.24980/rfcm.v3i5.1590

3. Agência Europeia para a Segurança no Trabalho. Facts n 6. Bruxelas: Agencia Europeia para Segurança no Trabalho; 2005.

4. Milczarek M, Brun E, Houtman I, Goudswaard A, Evers M, Bovenkamp M, et al. Expert forecast on emerging psychosocial risks related to occupational safety and health. European agency for safety and health at work. Luxembourg: European Communities; 2007. Available from: https://osha.europa.eu/en/tools-and-publications/publications/reports/7807118

5. Zeng JY, An FR, Xiang YT, Qi YK, Ungvari GS, Newhouse R, et al. Frequency and risk factors of workplace violence on psychiatric nurses and its impact on their quality of life in China. Psychiatry Res [Internet]. 2013 [cited 2019 Mar 25];210(2):510-4. Available from: http://dx.doi. org/10.1016/j.psychres.2013.06.013

6. Ferreira CAA, Vasconcelos FCW, Goulart IB, Ituassu CT. [Quality of work life: a critical view of mental health workers]. Revista Eletrônica Fafit/FacicBrasil [Internet]. 2015 [cited 2017 Apr 20];6(2):13-30. Available from: http://www.fafit.com.br/revista/index.php/fafit/article/ viewFile/134/75 Portuguese.

7. Portuné R. Psychosocial risks in the workplace: an increasing challenge for German and international health protection. Arh Hig Rada Toksikol [Internet]. 2012 [cited 2019 Mar 25];63(2):123-31. Available from: http://dx.doi.org/10.2478/10004-1254-63-2012-2212

8. Minayo MCS. O desafio do conhecimento: pesquisa qualitativa em saúde. 12th ed. São Paulo: Hucitec; 2012.

9. Machado SA, Oselame GB, Neves EB. [Profile evaluation and quality of life of nursing scholars]. Rev Aten Saúde [Internet]. 2016 [cited 2017 Apr 20];14(47):55-60. Available from: http://dx.doi.org/10.13037/rbcs.vol14n47.3417 Portuguese.

10. Ministério da Educação (BR). Pós-Graduação Lato Sensu: Saiba Mais [Internet]. Brasília: MEC; 2013 [cited 2017 Apr 20]. Available from: http:// portal.mec.gov.br/pos-graduacao

11. Rodrigues J, Santos SMA, Spriccigo JS. Teaching nursing care in mental health in undergraduate nursing. Acta Paul Enferm [Internet]. 2012 [cited 2017 Apr 20];25(6):844-51. Available from: http://dx.doi.org/10.1590/S0103-21002012000600004

12. Sulzbacher E, Fontana RT. [Conceptions of nursing staff about the exposure to physical and chemical risks in hospital environment]. Rev Bras Enferm [Internet]. 2013 [cited 2017 Apr 20];66(1):25-30. Available from: http://dx.doi.org/10.1590/S0034-71672013000100004 Portuguese.

13. Silva LMS, Fernandes MC, Mendes EP, Evangelista NC, Torres RAM. [Interdisciplinary work in the family health strategy: focus on care and management]. Rev Enferm UERJ [Internet]. 2012 [cited 2017 Apr 20];20(esp 2):784-8. Available from: http://www.e-publicacoes.uerj.br/ index.php/enfermagemuerj/article/view/6024/4329 Portuguese.

14. Guimarães JMX, Jorge MSB, Assis MMA. [(Dis)satisfaction with mental healthcare work: a study in psychosocial care centers]. Ciênc Saúde 
Colet [Internet]. 2011 [cited 2017 Apr 20];16(4):2145-54. Available from: http://dx.doi.org/10.1590/S1413-81232011000400014 Portuguese.

15. Lima Neto AV, Fernandes FL, Barbosa IML, Carvalho GRP, Nunes VMA. [Interpersonal relations between staff of an emergency hospital: a qualitative study under the look of nurses]. Enfermagem Revista [Internet]. 2015 [cited 2017 Apr 20];18(1):75-87. Available from: http:// periodicos.pucminas.br/index.php/enfermagemrevista/article/view/9371 Portuguese.

16. Kurcgant P. Gerenciamento em enfermagem. 2nd ed. Rio de Janeiro: Guanabara Koogan; 2010.

17. Oliveira EB, Silva AV, Perez Jr EF, Costa HF, Nascimento LP, Souza LAM. [Psychosocial risk factors in neonatal intensive care unit: impact to nurse's health]. Rev Enferm UERJ [Internet]. 2013 [cited 2017 Apr 20];21(4):490-5. Available from: http://www.facenf.uerj.br/v21n4/v21n4a12. pdf Portuguese.

18. Kirchhof ALC, Lacerda MR, Sarquis LMM, Magnago TSB, Gomes IM. [Understanding workload in occupational health research on nursing]. Colombia Med [Internet]. 2011 [cited 2017 Apr 20];42(Supl 1):113-9. Available from: http://www.bioline.org.br/pdf?rc11047 Portuguese.

19. Casarolli ACG, Eberhardt TD, Nicola AL, Fernandes LM. [Complexity level of assistance and nursing sizing in a emergency unit of a public hospital]. Rev Enferm UFSM [Internet]. 2015 [cited 2017 Apr 20];5(2):278-85. Available from: http://dx.doi.org/10.5902/2179769216811 Portuguese.

20. Casafus KCU, Dell'Acqua MCQ, Bocchi SCM. [Between success and frustration about nursing care systematization]. Esc Anna Nery [Internet]. 2013 [cited 2017 Apr 20];17(2):313-21. Available from: http://dx.doi.org/10.1590/S1414-81452013000200016 Portuguese.

21. OIT: Organização Internacional do Trabalho. Equilíbrio entre trabalho e família [Internet]. Brasília: OIT; 2011 [cited 2017 Apr 20]. Available from: https://www.ilo.org/brasilia/temas/g\%C3\%AAnero-e-ra\%C3\%A7a/WCMS_302653/lang--pt/index.htm

22. McCarthy A, Darcy C, Grady G. Work-life balance policy and practice: understanding line manager attitudes and behaviors. Human Res Manage Rev [Internet]. 2010 [cited 2019 Mar 25];20(2):158-67. Available from: https://doi.org/10.1016/j.hrmr.2009.12.001

23. Mantonvani C, Migon MN, Alheira FV, Del-Ben CM. Managing agitated or aggressive patients. Rev Bras Psiquiatr [Internet]. 2010 [cited 2019 Mar 25];32(Suppl.2):s96-103. Available from: http://dx.doi.org/10.1590/S1516-44462010000600006

24. Scherer ZAP, Scherer EA, Rossi PT, Vedana KGG, Cavalin LA. [Expressions of violence in the university environment: the view of nursing students]. Rev Eletr Enferm [Internet]. 2015 [cited 2017 Apr 20];17(1):69-77. Available from: http://dx.doi.org/10.5216/ree.v17i1.22983 Portuguese.

25. Teixeira Jr MAB, Sferra LFB, Bottcher LB. A importância do lazer para a qualidade de vida do trabalhador. Rev Conexão Eletr [Internet]. 2012 [cited 2019 Mar 25];9:581-95. Available from: http://www.aems.edu.br/conexao/edicaoanterior/Sumario/2012/

26. Ferreira RC, Varga CRR, Silva RF. [Working in multiprofessional teams:the perspectives of family health residents]. Ciênc Saúde Coletiva [Internet]. 2009 [cited 2017 Apr 20];14(Supl. 1):1421-8. Available from: http://dx.doi.org/10.1590/S1413-81232009000800015 Portuguese.

27. Melo MB, Barbosa MA, Souza PR. Job satisfaction of nursing staff: integrative review. Rev Lat Am Enfermagem [Internet]. 2011 [cited 2017 Apr 20];19(4):1047-55. Available from: http://dx.doi.org/10.1590/S0104-11692011000400026 